\title{
Notes
}

\section{A New Strategy for Teaching Plant Propagation by Distance Education}

\author{
Sandra B. Wilson ${ }^{1}$ and \\ Mack Thetford ${ }^{2}$
}

AdDitional INDEX WORDS. agricultural education, active learning, Web technology
Department of Environmental Horticulture, Institute of Food and Agricultural Sciences, University of Florida.

Authors gratefully acknowledge Lisa Hightower and Doug Johnson for technical support.

${ }^{1}$ Assistant professor, Indian River Research and Education Center, Fort Pierce, FL 34945.

${ }^{2}$ Associate professor, West Florida Research and Education Center, 5988 Highway 90, Building 4900, Milton,

The development of strategies to reach students who are placebound because of job, family, or community responsibilities is an important mission for land-grant colleges. Many land-grant universities have established distance learning systems (Murphy, 1996), and it is generally agreed that educational programming for place-bound students provides a needed scholastic opportunity for students, while strengthening undergraduate enrollment in agriculture (Tignor and Wilson, 1999). University of Florida (UF) currently has 11 videoconferencing network sites throughout the state where various courses in agriculture are offered. Delivery methods for distance education courses include interactive videoconferencing, narrative PowerPoint (RealPresenter; RealNetworks, Inc., Seattle), World Wide Web, and Web course tools (WebCT; WebCT Inc, Lynnfield, Mass). The onset of interactive video has created an opportunity to merge the on-site and off-site classes into one united class and to improve the effectiveness of educational programming. Russell (1999) compiled a large bibliography of research demonstrating that there is not a significant difference between standard and distance education learning. However, noted disadvantages of

Table 1. Course modules coordinated with interactive videoconferencing lectures and digital video. Lectures follow the sequential order as presented in the course textbook (Hartmann et al., 2002). Web-based lectures were narrated PowerPoint.

Module

$1 \quad$ How plant propagation evolved in human society

Biology of plant propagation

The propagation environment

Lecture: How genes impact plant propagation (D.A. Clark, Univ. of Florida)

Lecture: Greenhouse systems for plant production (G.A. Giacomelli, Univ, of Arizona)

Video: An overview of plug production and tour of facilities (Knox Nursery, Winter Garden, Fla.)

Video: Discussions about environmental control with G.A. Giacomelli and S.B. Wilson at Knox Nursery, Winter Garden, Fla.

Techniques of seed production and handling

Principles of propagation by seed

Techniques of propagation by seed

Lecture: Sexual or seed propagation: Pollination and seed production (B. Dehgan, Univ. of Florida)

Lecture: Unusual types of seed development (M.E. Tignor, Univ. of Vermont)

Lecture: Techniques of plug production and seed vigor (K.A. Moore, Univ. of Florida)

Video: An animated life cycle of angiosperms (S.B. Wilson, Univ. of Florida)

$3 \quad$ Principles of propagation by cuttings

Techniques of propagation by cuttings

Lecture: Propagation by cuttings (F.T. Davies, Texas A \& M University)

Video: Commercial woody and herbaceous plant production (Lake Brantley Plant Co., Longwood, Fla.)

Video: Discussions about rooting indices and hormone application for cuttings with F.T. Davies and M. Thetford at Lake Brantley Plant Co., Longwood, Fla.

Video: Discussions about rooted cutting production scheduling and stock plants with R.K. Schoellhorn and G. Griffith at Hatchett Creek Farm, Gainesville, Fla.

Video: Mechanization of propagation and tour of facility (Hatchett Creek Farm, Gainesville, Fla.)

$4 \quad$ Principles of grafting and budding

Techniques of grafting

Techniques of budding

Lecture: Grafting and budding fruit trees (J.G. Williamson, Univ. of Florida)

Video: Demonstrations of grafting and budding citrus (J.G. Williamson, Univ. of Florida)

$5 \quad$ Layering and its natural modifications

Principles and practices of clonal selection

Propagation by specialized stems and roots

Lecture: Mutations, chimeras, and variegation (S.M. Scheiber, Univ. of Florida)

6 Principles of tissue culture for micropropagation

Techniques for micropropagation

Lecture: In vitro shoot culture (M.E. Kane, Univ. of Florida)

Lecture: Somatic embryogenesis (W.A. Vendrame, Univ. of Florida)

Video: Demonstration of micropropagation using a laminar flow hood (N. Phillman, Univ. of Florida)

Video: Commercial micropropagation techniques and tour of facility (Agri-starts, Inc., Apopka, Fla.) 


\section{Notes}

teaching a course through interactive videoconferencing are 1 ) expense (\$60.00/site per hour), 2) an increase in the time it takes to present the lecture material, 3) poor resolution, and 4) scheduling and geographical difficulties associated with field trips. To minimize these issues, a hybrid course in plant propagation was developed (Wilson, 2002 ) to allow the instructor to interchange several delivery methods as needed to use classroom time most effectively, to minimize scheduling conflicts, and to maximize flexibility.

The UF plant propagation course (PLS 3221/5222C) was formerly taught live on-site at four locations throughout Florida and has recently been completely restructured for state-wide distance delivery. Distance lectures now originate from the Milton and Fort Pierce campuses and are broadcast to six designated campuses throughout Florida. Seventy-five percent of the lecture portion of the course is delivered via PowerPoint presentations or use of a document camera projected to each site with an interactive PictureTel videoconferencing codec system (Polycom, Inc., Pleasanton, Calif). Communication with students outside of lecture was achieved using WebCT, a provider of Web-based course managemente-learning systems for higher education. The remaining $25 \%$ of the lecture is contained on a compact disk (CD) designed to provide students background information or in depth detail that would otherwise reduce the allotted amount of classroom time necessary to present new lecture material.

For the CD, 13 faculty with specific expertise were invited from four universities, including UF, to record a narrative PowerPoint lecture that is complemented by digital video from various nurseries (Table 1 ). The CD is based on a series of Web pages created to function as a directory or index for the videos with brief descriptions about the nursery or speaker featured in the videos. Flash animation was created using Macromedia Flash 5 (Macromedia, Inc., San Francisco) to give an introduction to the CD and highlight the collaborative effort among the faculty at the University of Florida, Texas A\&M University, University of Vermont, and University of Arizona. In addition to narrative PowerPoint lectures and digital videos illustrating commercial propagation practices, the $\mathrm{CD}$ contains an animated angiosperm life cycle that features narrated graphics that describe the process of pollination, fertilization, and embryogenesis in detail.
This innovative hybrid course in plant propagation is one of the first of its kind to bring the state-wide expertise of faculty and the diversity of students together via interactive videoconferencing and Web-based technology. The interactive video conferencing portion of the course is currently offered to UF students every other fall semester. For educational purposes, a copy of the CD containing the Web-based portion of the course may be obtained directly from the author.

\section{Literature cited}

Hartmann, H.T., D.E. Kester, F.T. Davies, Jr., and R.L. Geneve. 2002. Plant propagation: Principles and practices. $7^{\text {th }}$ ed. Prentice Hall, Upper Saddle River, N.J.

Murphy, T.H. 1996. Agricultural education and distance education: The time is now. Agr. Educ. Mag. 68(11):3, 22-23.

Russell, T.L. 1999. The no significant difference phenomenon. IDEC Publishers, Montgomery, Ala.

Tignor, M.E. and S.B. Wilson. 1999. Sowing the seeds of a new horticulture sciences teaching program. Proc. Fla. State Hort. Soc. 112:255-260.

Wilson, S.B. 2002. Principles of plant propagation. 19 Mar. 2003. <http:// irrecenvhort.ifas.ufl.edu/Propagation/ Index/index.htm>. 